\title{
Productivity of Maize Varieties intercropped with Cassava in Lafia and Makurdi Locations, Southern Guinea Savanna, Nigeria
}

\author{
Idoko, J.A; Gabriel A.; Ugese, F. D
}

Department of Crop Production, University of Agriculture, P.M.B.2373, Makurdi, Nigeria

\begin{abstract}
Two experiments were conducted from 2015 to 2016 at the Teaching and Research Farm of the Federal University of Agriculture, Makurdi [Latitude 07 $45^{\prime}$ - $07^{\circ}$ $50^{\prime} \mathrm{N}$, Longtitude $08^{\circ} 45^{\prime}-08^{\circ} 50^{\prime}$ E, elevation $98 \mathrm{ml}$ in Benue State and the Research and Teaching Farm of the College of Agriculture, Lafia (Latitude 08.33N and Longitude 08.32E) in Nasarawa State, all located in Southern Guinea Savannah of Nigeria. The experiments sought to determine the performance of maize varieties when intercropped with cassava.The experiment was laid out as split-plot in randomized complete block design $(R C B D)$ with three replications. The main plot treatment comprised of two cropping systems [sole cropping (maize, cassava) and row intercropping (maize + cassava)] while the sub-plot treatment was 3 maize varieties [Quality Protein Maize (QPM), Suwan 1-1 and the Local]. Each sub plot consisted of 5 ridges spaced $1 \mathrm{~m}$ apart and $4 \mathrm{~m}$ long and the net plot was the three middle ridges, $3 \mathrm{~m}$ long. Intercropping severely depressed plant height at harvest, leaf area index at harvest, cob circumference, cob length, number of rows per cob, number of seeds per row, cob weight, grain yield and 100-ssed weight in Lafi and Makurdi. The highest grain yield of maize was produced when QPM was planted as a sole crop in Lafia (2.95t/ha) and Makurdi (2.99t/ha). However, values obtained from LEC and LER showed intercrop advantage. Similarly, intercropping decreased the growth and yield (plant height at harvest, root circumference, root length, number of marketable roots per plant, number of unmarketable roots per plant and root weight) of cassava in both locations. Intercropping cassava with Local maize produced the highest root weight in Lafia (8.50t/ha) and Makurdi (9.02t/ha) among the treatments intercropped. All LER and $L E C$ values were above 1.0 and 0.25 respectively in both locations. Values obtained for competitive ratio showed that maize was mnore competitive than cassava probably due to its height advantage.
\end{abstract}

Keywords - Maize Varieties, Lafia and Makurdi, RCBD.

\section{INTRODUCTION}

Maize (Zea mays L.) is an important annual cereal plant cultivated worldwide and it belongs to the (Hugar and Palled, 2008). It is extensively used in Nigeria. Maize is ranked second to wheat among the world's cereal crops in terms of total production, use and price relative to other cereals. It is used to produce a large variety of food and non-food products (Raemaekers, 2001). The total world production of maize is estimated at about 1,016,736,092 tons, with the United States, China, and Brazil being the highest world producers (FAOSTAT, 2013). In Africa, maize plays a valuable role in human diet, animal ration and as raw material for agro-based industries. Africa is a minor producer of maize accounting for only about $7 \%$ of global maize production (FARA, 2009). The largest producer of maize in Africa is Nigeria, accounting for about $14 \%$ of Africa's total production and about $1 \%$ of the total world production (FAOSTAT, 2013).

Cassava is a perennial woody shrub that generally grows from one to three meters in height (Onwene, 1978; Hershey, 2005). It is grown by poor resource farmers, many of them women, as main source for food security and income generation (FAO, 2002). The total world production of cassava is about 276.7 million tonnes FAOSTSAT (2014). Africa accounts for $58 \%$ of the total world production while Nigeria accounts for $34.2 \%$ of Africa's total production and $20 \%$ of the total world production. Nigeria produces 54 million tonnes of the total world production making it the world's largest producer. Other large scale producers of cassava in the world include Democratic Republic of Congo, Ghana Tanzania and Mozambique (FAOSTAT, 2014).

Intercropping is a very common practice in the Southern Guinea Savannah ecological zone of Nigeria. It is the growing of two or more crop species simultaneously on the 
same field (Andrews and Kassam, 1976).The success of any intercropping system depends mainly on selection of component crops (Vishwanatha et al., 2011). When two or more plants with different rooting systems, a different pattern of water and nutrient demand and a different above ground habit are planted together, water, nutrient and sunlight are used more effectively. One of the most important reasons to grow two or more crops together is the increase in productivity per unit of land (Preston, 2003).Information on the yield advantage and competitive abilities of maize/cassava intercropping systems in Southern Guinea Savanna of Nigeria is lacking. This study reported here sought to bridge this knowledge gap. The objectives of the study were:

i. To evaluate the suitability of three maize varieties for intercropping with cassava in Lafia and Makurdi.

ii. To determine the productivity of the maize/cassava intercropping in Lafia and Makurdi.

\section{MATERIAL AND METHODS}

\section{Experimental Locations}

Two experiments were conducted from 2015 to 2016 at the Teaching and Research Farm of the Federal University of Agriculture, Makurdi [Latitude $07^{\circ} 45^{\prime}-07^{\circ} 50^{\prime} \mathrm{N}$, Longtitude $08^{\circ} 45^{\prime}-08^{\circ} 50^{\prime} \mathrm{E}$, elevation $98 \mathrm{~m}$ ] in Benue State and the Research and Teaching Farm of the College of Agriculture, Lafia (Latitude 08.33N and Longitude 08.32E) in Nasarawa State, all located in Southern Guinea Savannah of Nigeria. The experiments sought to determine the performance of maize varieties when intercropped with cassava. Thirty core samples of soil were collected from different parts of the field from $0-30 \mathrm{~cm}$ and bulked into a composite sample and used for the determination of physical and chemical properties of the soil (see Table 1) before planting. Both the physical and chemical analyses were done in the Soil Science Laboratory of the University of Agriculture, Makurdi.

Table.1: Physical and chemical properties of the surface soil (0-15 cm) at the experimental sites in Makurdi and Ibi

\begin{tabular}{lll}
\multicolumn{3}{c}{ in 2015} \\
\hline Parameters & Makurdi & Lafia \\
\hline Sand $(\%)$ & 72.20 & 73.10 \\
Silt $(\%)$ & 12.20 & 11.30 \\
Clay $(\%)$ & 14.40 & 13.50 \\
Textural class & Sandy loam & Sandy loam \\
pH $\left(\mathrm{H}_{2} \mathrm{O}\right)$ & 5.93 & 6.30 \\
Organic Carbon $(\%)$ & 0.72 & 0.80
\end{tabular}

\begin{tabular}{|c|c|c|}
\hline Organic Matter (\%) & 1.25 & 1.36 \\
\hline Total Nitrogen $(\%)$ & 0.70 & 0.78 \\
\hline $\begin{array}{l}\text { Available } \quad \text { Phosphorus } \\
(\mathrm{ppm})\end{array}$ & 3.60 & 2.90 \\
\hline $\mathrm{Cal}^{2+} \mathrm{Cmol} \mathrm{kg}^{-1}$ soil) & 3.41 & 3.57 \\
\hline $\mathrm{Mg}^{2+}\left(\mathrm{Cmol} \mathrm{kg}^{-1}\right.$ soil $)$ & 1.62 & 1.70 \\
\hline $\mathrm{K}^{+} \mathrm{Cmol} \mathrm{kg}{ }^{-1}$ soil) & 0.29 & 0.30 \\
\hline $\mathrm{Na}^{+} \mathrm{Cmol} \quad \mathrm{kg}^{-1} \quad$ soil $)$ & 0.60 & 0.52 \\
\hline CEC Cmol kg-1 soil) & 6.25 & 6.40 \\
\hline Base Saturation (\%) & 94.40 & 95.00 \\
\hline
\end{tabular}

Treatment and Experimental Design

The experiment was laid out as split-plot in randomized complete block design (RCBD) with three replications. The main plot treatment comprised of two cropping systems [sole cropping (maize, cassava) and row intercropping (maize + cassava)] while the sub-plot treatment was 3 maize varieties [Quality Protein Maize (QPM), Suwan 1-1 and the Local]. Each sub plot consisted of 5 ridges spaced $1 \mathrm{~m}$ apart and $4 \mathrm{~m}$ long and the net plot was the three middle ridges, $3 \mathrm{~m}$ long.

\section{Crop Husbandry}

The experimental site was cleared and ridged using cutlasses and hoes. Maize and cassava were sown either as sole crop or intercrop on ridges on the same day in both experimental locations (18 April, 2016 and 18 June, 2016 in Lafia and Makurdi respectively). Maize seeds were dressed with Apron Plus ${ }^{\circledR}$ 50DS (10\% metalaxy, $1.34 \%$ furanthiocarb, $61 \%$ carboxin) at the rate of one sachet per three kilogrammes of seed. Three maize seeds were planted per hill by the side of the ridge. Cassava cuttings measuring $30 \mathrm{~cm}$ were planted at an angle of $45^{\circ}$ at the top of the ridge a spacing of $100 \mathrm{~cm}$ within rows. Maize was thinned to 2 seedlings/stand at 10 days after planting (DAP) while supplying was done to cassava at 14 DAP. Intercropping had a 1:1 (maize:cassava) row proportion. Fertilizer was applied to maize at the rate of $30 \mathrm{~kg} \mathrm{~N}, 30 \mathrm{~kg}$ P 205 and $30 \mathrm{~kg}$ K2O per hectare (BNARDA, 2003) obtained from NPK 15:15:15 in split doses at 3 and 6 WAP by side placement. At 4 W.A.P, cassava plots in both sole and intercropped were top dressed with $200 \mathrm{~kg}$ of NPK $15: 15: 15$ by side placement (BNARDA, 2003). Two manual weedings were done at 3 and 7 weeks after planting (WAP) respectively. This was followed by remoulding at 12 WAP. All these operations were carried out by hoe. Hand pulling of the weeds in the experimental plots was done when necessary. 'Best' ${ }^{\circledR}$ (Cypermithrin 10\% EC) at a dose of $60 \mathrm{ml}$ in 10 litres of water was used for the control of insect pest on 
maize and this was repeated at fortnightly interval.Harvesting was done as each component crop reached physical maturity. In all cases local implements (knives, cutlasses and hoes) were used for harvesting. Maize cobs were cut and sundried before threshing and winnowing.

\section{Data Collection}

Parameters measured for maize component included plant height at harvest, cob length, number of rows per cob, number of seeds per row grain yield and hundred seed weight. The characters measured for the cassava component were plant height at harvest, root circumference, root length, number of saleable roots per plant and weight of saleable roots per hectare. Saleable roots were fresh roots $\geq$ $150 \mathrm{~g}$.

Measures of intercrop productivity was determined by using land equivalent ratio (LER) as described by Ofori and Stern (1987) and land equivalent coefficient (LEC) as illustrated by Adetiloye et al. (1983). Competitive ratio (CR) which indicates the number of times by which one component crop is more competitive than the other was calculated using the formula proposed by Willey et al. (1980).

Standard procedures were followed in collecting all data and analysis was done using GENSTAT statistical software. Whenever differences between treatment means were significant, means were separated by Fishers Least Significant Difference at $5 \%$ level of probability.

\section{RESULTS}

\section{Maize Component}

\section{Plant Height at Harvest}

The main effect of cropping system and maize variety as well as the interaction effects of cropping system $\mathrm{x}$ maize variety on the plant height of maize at harvest was significant $(\mathrm{P} \leq 0.05)$ in Lafia and Makurdi.

Data from Table 3 showed that irrespective of the cropping system, Suwan 1-1 gave the highest plant height of maize at harvest in both locations. The lowest plant height of maize at harvest was produced when Local maize was intercropped (Table 3).

Sole cropping generally gave higher plant height of maize than intercropping in Lafia and Makurdi. Suwan 1-1 produced the highest plant height of maize in both locations among the varieties evaluated (Table 2).

\section{Leaf Area Index at Harvest}

The leaf area index of maize at harvest as influenced by the main effect of cropping system and maize variety as well as the interaction effects of cropping system $\mathrm{x}$ maize variety in Lafia and Makurdi was significant $(\mathrm{P} \leq 0.05)$.

QPM produced the highest leaf area index of maize at harvest in both locations when it was planted as sole and the difference was significantly higher than that produced by any other treatment. The lowest leaf area index of maize at harvest was produced when Local maize was intercropped with cassava (Table 3 ).

On a general note, sole cropping produced significantly higher leaf area index at harvest than intercropping in Lafia and Makurdi. QPM gave significantly higher leaf area index of maize than Suwan 1-1 which in turn produced significantly higher leaf area index than Local maize (Table 2).

\section{Cob Circumference}

The main effect of cropping system and maize variety as well as the interaction effects of cropping system $\mathrm{x}$ maize variety was significant $(\mathrm{P} \leq 0.05)$ on the cob circumference of maize in Lafia and Makurdi.

Values obtained for cob circumference of maize in Makurdi were higher than those of Lafia. In both locations, sole QPM gave the highest cob circumference of maize and this was significantly higher than that produced by any other treatment except when Suwan 1-1 was planted as sole. Local maize gave the lowest cob circumference in Lafia and Makurdi when it was intercropped (Table 3).

Sole cropping generally produced significantly higher cob circumference than intercropping in both location. QPM gave the highest cob circumference of maize in Lafia and Makurdi among the varieties but this was only significantly higher than Local maize (Table 2).

\section{Cob Length}

The main effect of cropping system and maize variety as well as the interaction effects of cropping system $\mathrm{x}$ maize variety was significant $(\mathrm{P} \leq 0.05)$ on the cob length of maize in Lafia and Makurdi.

Data presented in Table 3 showed that in Lafia, Suwan 1-1 produced the longest cob length when it was planted as sole but this was not so in Makurdi where Suwan 1-1 produced the highest cob length when it was intercropped. In Lafia, intercropped QPM gave the lowest cob weight of maize while in Makurdi, Local maize produced the shortest cob weight of maize (Table 3 ).

Generally, sole cropping produced significantly higher cob length of maize than intercropping in Lafia and Makurdi. Irrespective of the location, Suwan 1-1 produced significantly higher cob length of maize (Table 2). 
Table.2: Effect of Cropping System and Maize Variety on the Pant Height, Leaf Area Index Cob Circumference and Cob Length of Maize in Lafia and Makurdi.

\begin{tabular}{|c|c|c|c|c|c|c|c|c|}
\hline \multirow[t]{2}{*}{ Treatment } & \multicolumn{2}{|c|}{$\begin{array}{l}\text { Plant Height at } \\
\text { Harvest }\end{array}$} & \multicolumn{2}{|c|}{$\begin{array}{l}\text { Leaf Area Index at } \\
\text { Harvest }\left(\mathrm{cm}^{2}\right)\end{array}$} & \multicolumn{2}{|c|}{$\begin{array}{l}\text { Cob Circumference } \\
\text { (cm) }\end{array}$} & \multicolumn{2}{|c|}{$\begin{array}{l}\text { Cob Length } \\
(\mathrm{cm})\end{array}$} \\
\hline & Lafia & Makurdi & Lafia & Makurdi & Lafia & Makurdi & Lafia & Makurdi \\
\hline \multicolumn{9}{|l|}{ Cropping System } \\
\hline Intercropping & 162.00 & 184.82 & 174.97 & 194.14 & 12.98 & 13.91 & 24.22 & 27.83 \\
\hline Sole Cropping & 181.27 & 192.20 & 191.23 & 213.40 & 15.51 & 15.88 & 27.46 & 28.57 \\
\hline F-LSD (0.05) & 3.54 & 4.32 & 6.75 & 6.92 & 1.33 & 1.37 & 1.54 & 1.05 \\
\hline \multicolumn{9}{|l|}{ Maize Variety } \\
\hline QPM & 169.72 & 182.93 & 195.15 & 214.39 & 14.89 & 15.59 & 25.19 & 27.84 \\
\hline Suwan 1-1 & 174.97 & 198.99 & 184.20 & 204.49 & 14.30 & 14.97 & 27.50 & 29.70 \\
\hline Local & 170.22 & 183.62 & 169.95 & 192.44 & 13.55 & 14.13 & 24.83 & 27.07 \\
\hline F-LSD (0.05) & 3.54 & 4.95 & 7.55 & 7.32 & 1.19 & 1.25 & 1.31 & 1.44 \\
\hline
\end{tabular}

Table.3: Interaction Effects of Cropping System x Maize Variety on the Pant Height, Leaf Area Index Cob Circumference and Cob Length of Maize in Lafia and Makurdi.

\begin{tabular}{llllllllll}
\hline $\begin{array}{l}\text { Cropping } \\
\text { System }\end{array}$ & Maize Variety & \multicolumn{2}{l}{$\begin{array}{l}\text { Plant Height } \\
\text { Harvest }(\mathbf{c m})\end{array}$} & $\begin{array}{l}\text { Leaf Area Index } \\
\text { at Harvest }\left(\mathbf{c m}^{2}\right)\end{array}$ & $\begin{array}{l}\text { Cob } \\
\text { Circumference } \\
\text { (cm) }\end{array}$ & Cob Length $(\mathbf{c m})$ \\
\cline { 3 - 10 } & & Lafia & Makurdi & Lafia & Makurdi & Lafia & Makurdi & Lafia & Makurdi \\
\hline Intercropping & QPM & 161.23 & 180.43 & 186.50 & 196.55 & 13.77 & 14.67 & 22.95 & 27.00 \\
& Suwan 1-1 & 164.67 & 193.43 & 179.90 & 195.37 & 12.73 & 13.93 & 25.43 & 30.17 \\
& Local & 160.10 & 180.61 & 158.50 & 190.50 & 12.43 & 13.13 & 24.28 & 26.33 \\
Sole Cropping & QPM & 178.20 & 185.43 & 203.80 & 232.23 & 16.00 & 16.50 & 27.43 & 28.67 \\
& Suwan 1-1 & 185.27 & 204.54 & 188.50 & 213.60 & 15.87 & 16.00 & 29.57 & 29.23 \\
& Local & 180.33 & 186.63 & 181.40 & 194.37 & 14.67 & 15.13 & 25.38 & 27.80 \\
F-LSD (0.05) & & 3.54 & 3.99 & 7.64 & 7.74 & 1.32 & 1.71 & 2.11 & 2.24 \\
\hline
\end{tabular}

\section{Number of Rows per Cob}

The main effect of cropping system and maize variety as well as the interaction effects of cropping system $x$ maize variety was significant $(P \leq 0.05)$ on the number of rows per cob of maize in Lafia and Makurdi.

Data presented in Table 5 showed that in Lafia, QPM produced the same number of rows per cob and this represented the highest number of rows per cob in Lafia. In Makurdi, QPM produced the highest number of rows per cob when it was planted as sole but the difference was not significantly higher than that produced when Suwan 1-1 was also planted as sole crop (Table 5).

Sole cropping gave significantly higher number of rows per cob than intercropping in both locations. QPM gave the highest number of rows per cob among the varieties evaluated but the difference was only significantly higher than Local maize (Table 4).

Number of Seeds per Row
The number of seeds per row as influenced by the main effect of cropping system and maize variety as well as the interaction effects of cropping system $x$ maize variety in Lafia and Makurdi was significant $(\mathrm{P} \leq 0.05)$.

Regardless of the location, the highest number of seeds per row was produced when Suwan 1-1 was planted as a sole crop. In Makurdi, the number of seeds per row produced by sole Suwan 1-1 was not significantly different from that produced by sole QPM and intercropped Suwan 1-1. Intercropped Local maize gave the lowest number of seeds per row in both locations (Table 5).

Sole cropping largely gave higher number of seeds per row than intercropping in all locations and the difference was significant. Suwan 1-1 produced the highest number of seeds per row among the varieties evaluated (Table 4).

Cob Weight

The main effect of cropping system and maize variety as well as the interaction effects of cropping system $\mathrm{x}$ maize 
variety was significant $(\mathrm{P} \leq 0.05)$ on the number of rows per cob of maize in Lafia and Makurdi.

Cob weight values obtained from Makurdi were higher than those of Lafia. QPM produced the highest cob weight when it was planted as a sole crop in both locations but the difference was not significantly higher than that produced when Suwan 1-1 was planted as a sole crop. Local maize gave the lowest cob weight of maize when it was intercropped with cassava in Lafia and Makirdi (Table 5).

Sole cropping produced significantly higher cob weight in both locations than intercropping. QPM produced the highest cob weight among the varieties evaluated but the difference was only significantly higher than that produced by Local maize (Table 4).

\section{Grain Yield}

The grain yield of maize at harvest as influenced by the main effect of cropping system and maize variety as well as the interaction effects of cropping system $\mathrm{x}$ maize variety in Lafia and Makurdi was significant $(\mathrm{P} \leq 0.05)$.

Data presented in Table 5 revealed that Makurdi location produced higher grain yield values than Lafia location. In both locations, QPM gave the highest grain yield of maize when it was planted as sole but this was not significantly different from that produced when Suwan 1-1 was planted as sown and when QPM was intercropped (Table 5).

Sole cropping produced significantly higher grain yield of maize than intercropping in all locations. Irrespective of the location, QPM gave the highest grain yield of maize but this was only significantly higher than that produced by Local maize (Table 4).

\section{0-Seed Weight}

The main effect of cropping system and maize variety as well as the interaction effects of cropping system $\mathrm{x}$ maize variety was significant $(\mathrm{P} \leq 0.05)$ on 100 -seed weight of maize in Lafia and Makurdi.

Data presented in Table 5 showed that in Lafia, Local maize gave the highest 100-seed weight of maize when it was planted as a sole crop but this was not so in Lafia where Suwan 1-1 gave the highest 100-seed weight of maize when it was planted as a sole crop. In Lafia, Local maize gave the lowest 100-seed weight of maize when it was intercropped while intercropped Suwan 1-1 gave the lowest 100-seed weight in Makurdi (Table 5).

Sole cropping generally gave higher 100-seed weight of maize than intercropping in Lafia and Makurdi. Among the maize varieties evaluated, Local maize gave the highest 100-seed weight in Lafia and Makurdi (Table 4).

Table.4: Interaction Effects of Cropping System and Maize Variety on some Yield and Yield Parameters of Maize in Lafia and

\begin{tabular}{|c|c|c|c|c|c|c|c|c|c|c|}
\hline \multirow{3}{*}{ Treatment } & \multicolumn{8}{|c|}{ Makurdi } & \multirow{2}{*}{\multicolumn{2}{|c|}{$\begin{array}{l}\text { 100-Seed Weight } \\
\text { (g) }\end{array}$}} \\
\hline & \multicolumn{2}{|c|}{$\begin{array}{l}\text { Number of Rows } \\
\text { per Cob }\end{array}$} & \multicolumn{2}{|c|}{$\begin{array}{l}\text { Number of } \\
\text { Seeds per Row }\end{array}$} & \multirow{2}{*}{$\begin{array}{l}\begin{array}{l}\text { Cob } \\
\text { (t/ha) }\end{array} \\
\text { Lafia }\end{array}$} & \multirow{2}{*}{$\begin{array}{c}\text { Weight } \\
\text { Makurdi } \\
\end{array}$} & \multirow{2}{*}{$\begin{array}{l}\begin{array}{l}\text { Grain } \\
\text { (t/ha) }\end{array} \\
\text { Lafia }\end{array}$} & Yield & & \\
\hline & Lafia & Makurdi & Lafia & Makurdi & & & & Makurdi & Lafia & Makurdi \\
\hline $\begin{array}{l}\text { Cropping } \\
\text { System }\end{array}$ & & & & & & & & & & \\
\hline Intercropping & 16.01 & 15.00 & 23.11 & 26.46 & 3.83 & 4.13 & 2.06 & 2.35 & 30.42 & 31.20 \\
\hline Sole Cropping & 16.71 & 18.70 & 25.69 & 28.02 & 4.28 & 4.44 & 2.35 & 2.56 & 34.85 & 35.36 \\
\hline F-LSD $(0.05)$ & 0.42 & 1.45 & 1.57 & 1.93 & 0.36 & 0.22 & 0.24 & 0.19 & 1.54 & 1.83 \\
\hline Maize Variety & & & & & & & & & & \\
\hline QPM & 17.67 & 18.78 & 24.12 & 26.93 & 4.52 & 4.86 & 2.60 & 2.93 & 32.08 & 31.52 \\
\hline Suwan 1-1 & 17.30 & 17.50 & 26.00 & 28.54 & 4.32 & 4.43 & 2.52 & 2.56 & 32.42 & 34.00 \\
\hline Local & 14.12 & 14.27 & 23.09 & 26.25 & 3.33 & 3.58 & 1.50 & 1.89 & 33.41 & 34.33 \\
\hline F-LSD (0.05) & 1.54 & 1.93 & 1.67 & 1.88 & 0.53 & 0.34 & 0.23 & 0.45 & 1.03 & 1.13 \\
\hline
\end{tabular}

Table.5: Interaction Effects of Cropping System x Maize Variety on some Yield and Yield Parameters of Maize in Lafia and Makurdi

\begin{tabular}{|c|c|c|c|c|c|c|c|c|c|c|c|}
\hline \multirow[t]{2}{*}{$\begin{array}{l}\text { Cropping } \\
\text { System }\end{array}$} & \multirow[t]{2}{*}{$\begin{array}{l}\text { Maize } \\
\text { Variety }\end{array}$} & \multicolumn{2}{|c|}{$\begin{array}{l}\text { Number of Rows } \\
\text { per Cob }\end{array}$} & \multicolumn{2}{|c|}{$\begin{array}{l}\text { Number of Seeds } \\
\text { per Row }\end{array}$} & \multirow{2}{*}{$\begin{array}{l}\begin{array}{l}\text { Cob } \\
\text { (t/ha) }\end{array} \\
\text { Lafia }\end{array}$} & \multirow{2}{*}{$\begin{array}{r}\text { Weight } \\
\text { Makurdi }\end{array}$} & \multicolumn{2}{|c|}{$\begin{array}{l}\text { Grain Yield } \\
\text { (t/ha) }\end{array}$} & \multicolumn{2}{|c|}{$\begin{array}{l}\text { 100-Seed Weight } \\
\text { (g) }\end{array}$} \\
\hline & & Lafia & Makurdi & Lafia & Makurdi & & & Lafia & Makurdi & Lafia & Makurdi \\
\hline \multirow[t]{2}{*}{ Intercropping } & QPM & 17.67 & 17.33 & 24.00 & 25.43 & 4.14 & 4.75 & 2.25 & 2.87 & 31.00 & 29.70 \\
\hline & $\begin{array}{l}\text { Suwan } \\
1-1\end{array}$ & 17.36 & 15.00 & 23.33 & 28.31 & 4.11 & 4.21 & 2.28 & 2.35 & 29.32 & 29.57 \\
\hline
\end{tabular}




\begin{tabular}{|c|c|c|c|c|c|c|c|c|c|c|c|}
\hline \multirow{4}{*}{$\begin{array}{l}\text { Sole } \\
\text { Cropping }\end{array}$} & Local & 13.00 & 12.67 & 22.00 & 25.63 & 3.24 & 3.44 & 1.65 & 1.84 & 30.95 & 34.33 \\
\hline & QPM & 17.67 & 20.23 & 24.23 & 28.42 & 4.90 & 4.96 & 2.95 & 2.99 & 33.15 & 33.33 \\
\hline & & & & & & & & & & & \\
\hline & $\begin{array}{l}\text { Suwan } \\
1-1\end{array}$ & 17.24 & 20.00 & 28.67 & 28.77 & 4.52 & 4.64 & 2.75 & 2.76 & 35.52 & 38.43 \\
\hline & Local & 15.23 & 15.87 & 24.17 & 26.87 & 3.41 & 3.71 & 1.34 & 1.94 & 35.87 & 34.33 \\
\hline F-LSD (0.05) & & 1.25 & 1.32 & 1.22 & 1.32 & 0.46 & 0.34 & 0.45 & 0.23 & 1.34 & 1.76 \\
\hline
\end{tabular}

\section{Plant Height at Harvest}

Cropping system and maize varieties had significant $(\mathrm{P} \leq$ 0.05 ) effect on the plant height of cassava at harvest. In all locations, sole cropping generally gave higher plant height of cassava at harvest than intercropping. Among the cassava treatments intercropped, cassava produced the highest plant height in Makurdi and Lafia when it was intercropped with QPM (Table 6).

\section{Root Circumference}

The root circumference of cassava as influenced by the main effect of cropping system and maize variety was significant $(\mathrm{P} \leq 0.05)$ in Lafia and Makurdi. Irrespective of the location, sole cassava produced the highest root circumference and this was significantly higher than that produced by any other treatment. Cassava intercropped with Local maize and cassava intercropped with Suwan 1-1 gave the highest and lowest root circumference of cassava in both locations respectively (Table 6).

\section{Root Length}

The root length of maize as influenced by the effect of cropping system and maize variety was significant $(\mathrm{P} \leq$ 0.05) in Lafia and Makurdi. In all locations, sole cassava produced significantly higher root length than cassava intercropped with Local maize which in turn gave significantly higher root length than cassava intercropped with QPM and Suwan 1-1 respectively (Table 6).

Table.6: Plant Height, Root Circumference and Root Length of Cassava as Influenced by Cropping System and Maize Variety in Lafia and Makurdi

\begin{tabular}{|c|c|c|c|c|c|c|}
\hline \multirow[t]{2}{*}{ Treatment } & \multicolumn{2}{|c|}{$\begin{array}{l}\text { Plant } \\
\text { Height } \\
\text { Harvest }(\mathbf{c m})\end{array}$} & \multicolumn{2}{|c|}{$\begin{array}{l}\text { Root } \\
\text { Circumference } \\
\text { (cm) }\end{array}$} & \multicolumn{2}{|c|}{$\begin{array}{l}\text { Root Length } \\
\text { (cm) }\end{array}$} \\
\hline & Lafia & $\begin{array}{l}\text { Maku } \\
\text { rdi }\end{array}$ & Lafia & Makurdi & Lafia & $\begin{array}{l}\text { Makur } \\
\text { di }\end{array}$ \\
\hline Cassava + QPM & 130.73 & 158.67 & 16.00 & 17.93 & 38.67 & 42.33 \\
\hline Cassava + Suwan 1-1 & 120.90 & 128.33 & 13.67 & 14.37 & 33.00 & 37.33 \\
\hline Cassava + Local & 117.90 & 140.90 & 17.00 & 19.33 & 43.78 & 47.00 \\
\hline Intercrop Mean & 123.18 & 142.63 & 15.56 & 17.21 & 38.48 & 42.22 \\
\hline Sole Cassava & 147.18 & 163.18 & 24.00 & 25.80 & 53.28 & 55.53 \\
\hline Grand Mean & 129.18 & 147.77 & 17.67 & 19.36 & 42.18 & 45.55 \\
\hline F-LSD (0.05) & 5.54 & 65.43 & 2.34 & 2.65 & 4.74 & 4.32 \\
\hline
\end{tabular}

\section{Number of Marketable Roots per Plant}

Cropping system and maize varieties had significant $(\mathrm{P} \leq$ 0.05 ) effect on the number of marketable roots per plant in Lafia and Makurdi. Regardless of the location, sole cassava produced the highest number of marketable roots per plant and this was significantly higher than that produced by any other treatment. In all locations, no significant difference was observed among the cassava treatments intercropped (Table 7).

\section{Number of Unmarketable Roots per Plant}

The number of unmarketable roots per plant as influenced by the effect of cropping system and maize variety was significant $(\mathrm{P} \leq 0.05)$ in Lafia and Makurdi. In both locations, sole cropping had the highest number of unmarketable roots per plant and the difference was significant. No significant difference was observed on the number of marketable per plant among the treatments intercropped (Table 7).

\section{Root Weight}


The root weight of maize as influenced by the effect of cropping system and maize variety was significant $(\mathrm{P} \leq$ 0.05 ) in Lafia and Makurdi.

Sole cassava produced significantly higher root weight in both locations and this was significantly higher than that produced by any other treatment. Cassava intercropped with Local maize gave the highest root weight of cassava among the treatments intercropped and the difference was significant (Table 7).

Table.7: Effect of Cropping System and Maize Variety on the Number of Marketable and Unmarketable roots per Plant and Root Weight of Cassava in Lafia and Makurdi

\begin{tabular}{|c|c|c|c|c|c|c|}
\hline \multirow[t]{2}{*}{ Treatment } & \multicolumn{2}{|c|}{$\begin{array}{l}\text { Number of } \\
\text { Marketable } \\
\text { Roots per Plant }\end{array}$} & \multicolumn{2}{|c|}{$\begin{array}{l}\text { Number of } \\
\text { Unmarketable } \\
\text { Roots per Plant }\end{array}$} & \multicolumn{2}{|c|}{$\begin{array}{l}\text { Root Weight } \\
\text { (t/ha) }\end{array}$} \\
\hline & Lafia & $\begin{array}{l}\text { Maku } \\
\text { rdi }\end{array}$ & Lafia & $\begin{array}{l}\text { Maku } \\
\text { rdi }\end{array}$ & Lafia & $\begin{array}{l}\text { Makur } \\
\text { di }\end{array}$ \\
\hline Cassava + QPM & 9.00 & 9.30 & 2.00 & 1.50 & 6.58 & 7.09 \\
\hline Cassava + Suwan 1-1 & 9.50 & 9.67 & 1.67 & 1.67 & 6.73 & 7.60 \\
\hline Cassava + Local & 9.67 & 10.67 & 1.17 & 1.33 & 8.50 & 9.02 \\
\hline Intercrop Mean & 9.39 & 9.88 & 1.61 & 1.50 & 7.27 & 7.90 \\
\hline Sole Cassava & 15.43 & 16.00 & 3.83 & 3.50 & 12.35 & 12.88 \\
\hline Grand Mean & 10.90 & 11.41 & 2.17 & 2.00 & 8.54 & 9.15 \\
\hline F-LSD (0.05) & 2.43 & 2.03 & 1.43 & 1.55 & 1.54 & 1.65 \\
\hline
\end{tabular}

\section{Assessment of Measures of Intercrop Productivity}

Table 8 presents the results of measures of intercrop productivity [Land Equivalent Ratio (LER), Land Equivalent Coefficient (LEC)] and measures of competitive interactions [Competitive Ratio (CR)] between the intercrop components of maize and cassava in Lafia and Makurdi.
All intercrop combinations had LER figures above 1.0 and LEC values above 0.25 in both locations. CR values of maize were consistently higher than those of cassava in all intercrop combinations. The combination of cassava and Local maize had higher values of LER and LEC than the other combinations (Table 8).

Table.8: Land Equivalent Ratio (LER), Land Equivalent Coefficient (LEC) and Competitive Ratio (CR) of Intercropped Maize Varieties with Cassava in Lafia and Makurdi

\begin{tabular}{|c|c|c|c|c|c|c|c|c|}
\hline \multirow[t]{2}{*}{ Treatment } & \multicolumn{2}{|l|}{ LER } & \multicolumn{2}{|l|}{ LEC } & \multicolumn{2}{|c|}{ CR Maize } & \multicolumn{2}{|c|}{ CR Cassava } \\
\hline & Lafia & $\begin{array}{l}\text { Makur } \\
\text { di }\end{array}$ & Lafia & $\begin{array}{l}\text { Makur } \\
\text { di }\end{array}$ & Lafia & $\begin{array}{l}\text { Makur } \\
\text { di }\end{array}$ & Lafia & $\begin{array}{l}\text { Makur } \\
\text { di }\end{array}$ \\
\hline Cassava + QPM & 1.41 & 1.65 & 0.50 & 0.67 & 1.17 & 1.38 & 0.85 & 0.72 \\
\hline $\begin{array}{l}\text { Cassava + Suwan } \\
1\end{array}$ & 1.44 & 1.49 & 0.51 & 0.54 & 1.35 & 1.33 & 0.74 & 0.75 \\
\hline Cassava + Local & 2.11 & 1.83 & 1.08 & 0.84 & 1.40 & 1.07 & 0.71 & 0.93 \\
\hline Grand Mean & 1.65 & 1.66 & 0.70 & 0.68 & 1.31 & 1.26 & 0.77 & 0.80 \\
\hline F-LSD (0.05) & 0.13 & 0.24 & 0.14 & 0.16 & 1.07 & 1.25 & 0.34 & 0.23 \\
\hline
\end{tabular}

\section{DISCUSSION}

The depression in plant height at harvest, leaf area index at harvest, cob circumference, cob length, number of rows per cob, number of seeds per row, cob weight, grain yield and 100-seed weight of maize as compared to sole crop resulted from inter-specific competition. Egbe and Adeyemo (2006) had also reported reduction in growth and yield of some component crops in mixtures. These authors opined that inter- specific competition for light, nutrients, water, air and other growth resources often resulted in depressed yields of the intercrop components. 
Growth and yield of maize varied with variety. In all locations, Suwan 1-1 generally produced the highest plant height at harvest, cob length and number of seeds per row. QPM gave the highest leaf area index at harvest, cob circumference, number of rows per cob, cob weight and grain yield in Lafia and Makurdi. Suwan 1-1 produced the highest 100-seed weight of maize in Lafia while Local maize gave the highest 100 -seed weight of maize in Makurdi. The result obtained from this study suggests that selection for these characters would be effective for further selection and improvement. The superior performance of these varieties with respect to various parameters was due to their genetic makeup. Differences in their anatomical, morphological and physiological structures enabled them to compete effectively with the component crop, absorb nutrients and water, effectively carry out photosynthesis and store photosynthates which other varieties could not. Plants respond differently to environmental factors based on their genetic makeup and their adaptation capability indicating variability among species (Agbogidi and Ofuoku, 2005; Agbogidi and Egho, 2012).

The decrease in growth and yield (plant height at harvest, root circumference, root length, number of marketable roots per plant, number of unmarketable roots per plant and root weight) of intercropped cassava as compared to sole cropping could be credited to interspecies rivalry for both under- and above-ground growth resources (water, nutrients, light, air, etc.). The taller maize component sheltered the low canopy cassava thus decreasing light availability for optimum photosynthetic activity and subsequently culminating in the low yields of cassava. Sharing of growth resources among components crops under intercropping can limit growth and accumulation of dry matter compared to sole cropping where competition exists (Dasbak and Asiegbu, 2009). The better performance of cassava under intercropping with Local maize over other varieties of maize with respect to root circumference, root length, number of unmarketable roots per plant and root weight suggest that this variety was more suitable than the other varieties for cultivation with cassava in Lafia and Makurdi environment.

LER values were greater than unity in all treatments in both locations, indicating the advantage of intercropping over sole stands in regard to use of environmental growth resources. All LEC values were above 0.25 in Lafia and Makurdi. This further indicates that all intercropping combinations were better in resource use efficiency compared to growing the two crops separately. Adetiloye et al. (1983) stated that the minimum expected production before a yield advantage is obtained in a two-crop mixture is an LEC greater than 0.25 (Egbe et al., 2010). The highest LER and LEC in both locations was obtained when Local maize was intercropped with cassava. Intercropping thus, can be the most realistic cropping system to increase crop productivity in Lafia and Makurdi environments. Maize was the more dominant component of the maize/cassava intercropping systems, probably because of its height advantage.

Fujita and Ofosu-Budu (1996)stated that the non-legume growth is severely suppressed due to depression of photosynthesis through decreases in irradiance.

\section{CONCLUSION}

Intercropping severely depressed plant height at harvest, leaf area index at harvest, cob circumference, cob length, number of rows per cob, number of seeds per row, cob weight, grain yield and 100-ssed weight in Lafi and Makurdi. In both locations, Suwan 1-1 generally produced the highest plant height at harvest, cob length and number of seeds per row. QPM gave the highest leaf area index at harvest, cob circumference, number of rows per cob, cob weight and grain yield in Lafia and Makurdi. Suwan 1-1 produced the highest 100 -seed weight of maize in Lafia while Local maize gave the highest 100 -seed weight of maize in Makurdi. Intercropping also decreased the growth and yield (plant height at harvest, root circumference, root length, number of marketable roots per plant, number of unmarketable roots per plant and root weight) of cassava in both locations. All LER and LEC values were above 1.0 and 0.25 respectively in both locations. Maize had higher competitive ratio values than cassava.

\section{REFERENCES}

[1] Adetiloye P.O., Ezedinma F.O.C. and Okigbo B.N. (1983). A land coefficient concept for evaluation of competitive and productive interactions on simple complex mixtures. Ecological Modelling, 19: 27-39.

[2] Agbogidi, O.M., Egho, E.O. (2012). Evaluation of eight varieties of cowpea (Vigna unguiculata (L.) Walp.) in Asaba agro-ecological environment, Delta State, Nigeria. Euro. J. Sustain. Dev. 1(2):303314.

[3] Agbogidi, O. M. and Ofuoku, A.U. (2005). Response of sour sop (Annona muricata Linn.) to crude oil levels. Journal of Sustainable Tropical Agricultural Research16: 98-102.

[4] Andrews, D.J. and Kassam, A.H. (1976). The importance of multiple cropping in increasing world 
food supplies. In: Papendick, R.I., Sanchez, R.A., and

Triplett, G.B., eds. Multiple cropping. 1st ed, Madison, USA: American Society of Agronomy, pp 110.

[5] Benue State Agricultural and Rural Development Authority (BNARDA). (2003): Annual Report, 2003, Makurdi, Nigeria.

[6] Dasbak, M.A.D., Asiegbu, J.E., (2009). Performance of pigeon pea genotypes intercropped with maize under humid tropical ultisol conditions. Journal of Animal and Plant Sciences 4 (2): 329-340.

[7] Egbe, O.M. and Adeyemo, M.O. (2006). Estimation of the effects of intercropped pigeonpea on the yield and yield components of maize in Southern Guinea Savanna of Nigeria. J. of Sustain. Dev. in Agric. AndEnviron. 2: 107-119.

[8] Egbe, O.M. Alibo, S.E. and Nwueze, I. (2010). Evaluation of some extra-early- and earlymaturing cowpea varieties for intercropping with maize in southern Guinea Savanna of Nigeria. Guinea Savanna of Nigeria. Agriculture and Biology Journal of North America, 1(5): 845-858.

[9] FAOSTAT (2009). Food and Agriculture Organization of the United Nations, Rome. http://faostat.fao.org//site/567/default.aspx\#ancor

[10]FAOSTAT (2014). Food and Agriculture Organization of the United Nations, Rome. http://faostat.fao.org//site/567/default.aspx\#ancor

[11]FARA (2009). Forum for Agricultural Research in Africa (FARA). Patterns of change in maize production in Africa: Implications for maize policy development. Networking Support Function 3. Regional Policies and Markets. Ministerial Policy Brief Series.

[12] Fujita,K. and Ofosu-Budu,K.G.(1996). Significance of legumes in intercropping systems, In: Ito,O., Katayama,K., Johansen, C., Kumar Rao, J.V.D.K.., Adu-Gyamfi, J.J. and Rego,TJ (eds.) Roots and nitrogen in cropping systems of the semi-arid troipcs. JIRCAS Int. Agric.Series No.3, Japan. pp 1940

[13] Hershey, C.H. (2005). Cassava Genetic Improvement: Theory and Practice.CIAT/Rockefeller.

[14]Hugar, H.Y. and Palled, Y.B. (2008) Effect of intercropping vegetables on maize and associated weeds in maize-vegetable intercropping systems. Karnataka. J. Agric. Sci. 21(2):159-161.
[15] Ofori, F. and Stern, W.R. (1987). Cereal -legume intercropping systems. Advances in Agronomy, 41:41-90.

[16] Onwuene, I.C. (1978). The Tropical Tuber Crops: Yams, Cassava, Sweetpotato, Cocoyams. John Wiley, Sons Ltd. pp 234.

[17] Preston, S. (2003). Intercropping Principles and Production Practices. ATTRA Publication, pp 1-10. Raemaekers, R. H. (2001). Crop Production in Tropical Africa, CIP Royal Library Albert 1, Brussel.

[18] Vishwanatha, S., Koppalkar, B. G., Anilkumar, S. N., Desai, B. K. and Vinayak, N. (2011). Economics and yield advantages of pigeonpea and sunflower intercropping system influenced by fertilizer management. Research Journal of Agricultural Sciences, 2(2): $\quad$ 248-251

[19] Willey, R.W., Matarajan, M., Reddy, M.S., Rao, M.R., Nambiar, P.T.C., Kammainan J. and Bhatanagar, V.S. (1980). Intercropping studies with annual crops. In "Better crops for food". J.C.Homeless (ed) Ciba Foundation Symp. pp. 83.97.

[20] Attia, T., Martin, T., Forbuzie, T., Angwafo, T. and Chuo, M. (2018). Human Wildlife Conflict: Causes, Consequences and Management Strategies in Mount Cameroon National Park South West Region, Cameroon. International Journal of Forest, Animal and Fisheries Research, 2(2), pp.34-49. 